
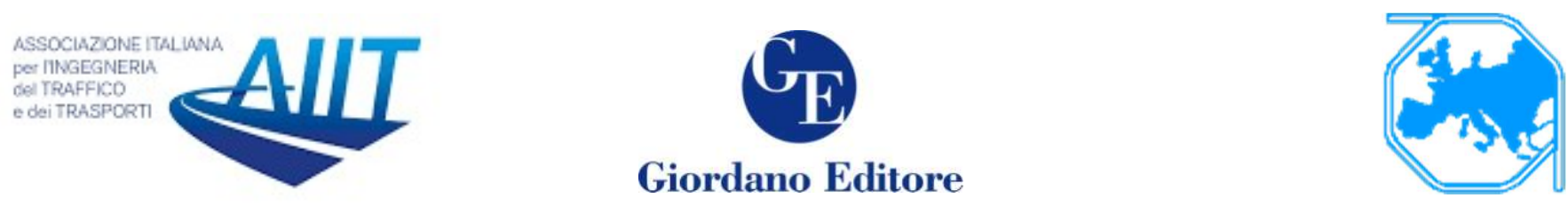

\title{
Commuters' Perceptions on Service Quality of Bus Rapid Transit Systems: Evidence from the Cities of Ahmedabad, Surat and Rajkot in India
}

\author{
Mahesh L. Chaudhary ${ }^{1 *}$ \\ ${ }^{1}$ Assistant Professor of Management \\ Gujarat National Law University, Gandhinagar \\ Gujarat, India
}

\begin{abstract}
Urban public transport is gaining significant importance in today's world. This is evident from the fact that it has found its place in United Nations Development Programme's Sustainable Development Goals in the eleventh goal pertaining to 'Sustainable cities and communities'. The competitiveness of the cities largely depends on the robustness of their transport systems. In India there has been huge spending on the public transport projects in cities across the country. Ahmedabad, Surat and Rajkot from Gujarat, India have been the beneficiaries of these investments. Capturing the demand side quality of services is very important for such projects and hence the attempt has been made to study whether the commuters' perceptions on quality of services of Bus Rapid Transit systems vary across different demographic cohorts. There are nine demographic cohorts used for the study. SERVPERF model has been adopted to study the performance of Bus Rapid Transit systems in the said citied. The performance is evaluated over the six factors namely; tangibles, empathy, cleanliness, reliability, safety and affordability. It has been found that Surat tops among the three cities followed by Rajkot and Ahmedabad on various service quality factors. Also commuters' perception towards quality of service dimensions vary across demographic cohorts like gender, time of travel, education, employment status, length of patronization and purpose of trip.
\end{abstract}

Keywords: Public Transport, SERVPERF, SERVQUAL, Bus Rapid Transit System, Customer Perception, Customer Service

\section{Introduction}

Bus Rapid Transit (BRT) systems are introduced in Indian cities with the motivation to provide high quality, modern rapid transit systems to deliver fast, comfortable, economical and safe mobility to urban dwellers. Despite heavy investments in the organized public transport systems like BRT systems and Metro, the private ownership of vehicles is sky rocketing across Indian cities. However, it will be very inapt to conclude that the investments in such public transit systems are worthless. On the contrary, one should understand that populous cities in India can come to a standstill if there is no public transport. Subsequently, this may put a brake on the growth momentum of the cities as

\footnotetext{
* Corresponding author: Mahesh L. Chaudhary (maheshchaudhary05@gmail.commchaudhary@.gnlu.ac.in)
} 
they might not be able to function efficiently. It is emphasized by Singh (2012) that economic efficiency of cities and well-being of urban dwellers are directly influenced by mobility or the lack of it. Put differently, transportation which facilitates movement of people, goods, and services is an essential requirement for cities to qualify as vibrant cities (Terry and Julia, 2011).

Unlike goods and services offered by private sectors, the public goods and services rendered by the state are largely kept aloof of the scrutiny for its quality of services. This could partly be associated with the fact that most of the time public goods and services are provided by the state and it either does not face competition or it may be assuming that public services are mandatory obligations that needs to be fulfilled just bare minimally. However, this lax attitude, especially in developing and under-developed countries, gradually ensures that the quality of public services keeps dwindling. Urban public transport services too are victim of this mindset. This is seconded by Andreassen (1994) wherein he said that the quality of the public transport service dwindles down with public transport organizations growing older and mature and the public is left with the only option of accepting what is offered.

The role of the state is not just to provide the public transport services, but also to ensure that quality of these services are such that they lead to commuters' satisfaction. Customers' (BRT system commuters) satisfaction depends on whether the public transport system is able to meet the expectations of the customers or not on various factors. A basic marketing management concept on customer satisfaction says that a customer is satisfied when the customer perception about the quality of services meets the expectation of the quality of those services and vice versa. Customers form service expectations from many sources, such as personal past experiences, advertising, word of mouth and many other channels (Voss, Parasuraman, and Grewal, 1998). Service quality is a very important ingredient understanding consumer behaviour. A positive consumer behaviour on service quality will help organization gain competitive advantage over its competitors and allows the organization to have profit margins higher than its competitors (Boulding et al., 1993; Zahorik and Rust, 1992; Zeithaml et al., 1996; \&Liu et al., 2000 as cited in Kokku et al., 2011).

With this backdrop, an enquiry into the commuters' perception towards the service quality of BRT systems in three major cities of Gujarat namely; Ahmedabad, Surat and Rajkot is attempted. The study aims at how do the commuters' perceptions towards the service quality of BRT system vary based on different demographic cohorts. The nine demographic cohorts used are respondents' city of commute, gender, age, education, employment status, travel time, frequency of BRTS travel, purpose of the BRTS trip made, length of the patronization of BRTS.

This paper advances with an overview of the existing literature that inquires quality of service and how this issue has been examined so far in the transport studies. Subsequent to it, the study area is introduced wherein the characteristics of BRT systems in the three cities and general demographic indicators are discussed. Following this, is the research methodology adopted for the study and data analysis using descriptive and inferential statistics. Subsequently, the findings of the analysis are discussed and the conclusion is drawn out of the findings that could be useful to various stakeholders. 


\section{Literature Review:}

\subsection{Early developments pertaining to service quality studies}

Efforts in defining and measuring quality can be traced back to goods sector through the Japanese philosophy on quality that says quality is "zero defects - doing it right the first time." (Parasuraman et al., 1985). Quality also means "conformance to requirements" (Crosby, 1979). According to Garvin (1983), quality is measured by counting the number of incidence of "internal" failures - failures observed before a product leaves the factory, and the "external" failures - failures incurred in the field after a product has been installed.

However, when it comes to understanding the service quality, the knowledge about the goods quality is insufficient because the three important characteristics of services intangibility (most services cannot be counted, measured, inventoried, tested, and verified in advance of sale to assure quality), heterogeneity (service performance often varies from producer to producer, from customer to customer, and from day to day), and inseparability (production and consumption of many services are inseparable) are not captured in the early discussions pertaining to goods quality. But, researchers and managers of service firms in the 1970s \& 80s concur that service quality involves comparison of expectations with performance. Lewis and Booms (1983) in their evaluation said that service quality is a measure of how well the service level delivered matches customer expectations. Delivering quality service means conforming to customer expectations on a consistent basis. The quality in service provision got much impetus towards the end of the twentieth century because of the increasing prominence of the service sector in the industrialized economies of the world (Grönroos, 1984). There is ample research done on service quality from different aspects (Grönroos, 1982; Berry et al., 1985; Parasuraman et al., 1985; Zeithaml et al., 1985; \& Brady and Cronin, 2001).

\subsection{Unfolding techniques for the measurement and evaluation of service quality}

Policies and strategies pertaining to improvement in service quality cannot be pursued without evaluation of the current level of quality in the service provision. Therefore, developing techniques which allow quality of service to be measured represents an issue which attracted significant attention from researchers around the world (Morton et al., 2016).

The prominent technique to measure and evaluate the quality of service was SERVQUAL. The SERVQUAL scale, based on Parasuraman, Zeithaml, and Berry's (1985) gap theory, suggests that the difference between consumers' expectations about the performance of a general class of service providers and their assessment of the actual performance of a specific firm within that class drives the perception of service quality (Cronin \& Taylor, 1992). In other words, SERVQUAL is a technique to measure the quality of service wherein each of the quality of service dimensions is considered by measuring both customer expectations of service quality and the perceived performance level of service quality and evaluating the gap which exists between these two measurements. Customers are believed to be satisfied when the performance meets expectations while they are deemed to be dissatisfied when the performance falls short of expectations. SERVQUAL was initially developed out of an in-depth qualitative assessment of how quality of service is discussed by service providers and service customers (Parasuraman et al. 1985) which suggested that ten determinants of service quality are present across a variety of different service contexts (Morton et al., 2016). The 
evolution of these ten determinants finally led to multi-item measurement scale which covered five dimensions of service quality namely; tangibility, reliability, responsiveness, assurance and empathy (Parasuraman et al., 1988). Further refinements in SERVQUAL were made to improve the reliability, validity and ease of application (Parasuraman et al., 1991\& 1994).

Concurrently, a good number of researchers have identified a number of limitations associated with this technique. The major problem with the literature on SERVQUAL is its hesitancy to call perceived service quality an attitude (Cronin \& Taylor, 1992). Oliver (1980) suggests that atttitude is initially a function of expectations and subsequently a function of the prior attitude toward and the present level of satisfaction with a product or service. With this backdrop, if one considers service quality to be an attitude, Oliver (1980) suggests that service quality and consumer satisfaction are distinct constructs, but are related in that satisfaction mediates the effect of prior-period perceptions of service quality to cause a revised service quality perception to be formed. This resoning is consistent with Bolton's and Drew's (1991 a) findings and also calls into question the use of the disconfirmation framework, as the primary measure of service quality, as found in SERVQUAL technique.

Cronin and Taylor (1992) argue that considering service quality to represent an attitude of a customer as agaisnt the gap between expectation and performance allows the measurement to connect with conventional psychological theory. This subsequently gave birth to the SERVPERF that deals with perceived performance in service quality (Cronin and Taylor, 1994). SERVPERF technique is based on Mazis et al. (1975) experimental evidence which suggests that the performance dimension alone predicts behavioural intentions and actual behaviour. This finding suggests using only performance perceptions as a measure of service quality. Buttle et al. (1996) too highlighted theoretical limitations of SERVQUAL by questioning the universality of the service quality dimensions embedded in SERQUAL in terms of the convergent and discriminant validity of the dimensions (Asubonteng et al., 1996).

Whilst SERVQUAL and SERVPERF represent reductionist techniques which allow for straightforward deployment and evaluation, Gilmore and McMullan (2009) argue that the use of qualitative techniques, such as focus groups and interviews with customers, alongside applications of quantitative measurements can enhance understanding concerning the specific issues surrounding the perceptions of service quality in different settings. Taking a multi-method approach which integrates quantitative and qualitative elements would allow researchers to consider what Buttle et al. (1996) describe as the nebulous nature of the quality of service concept.

\subsection{Applications of techniques for the measurement and evaluation of service quality in the domain of transportation}

The study of perceptions of commuters to quality of commuting serices can serve the dual purpose of retaining the existing commuters and attracting the new commuters from other service providers or transport modes (Morton, et al., 2016). There exists a large body of research concerning quality of service in the transport sector using different methodology. A large number of attributes, which may be categorized as physical and perceived, have been proposed in attempts to define public transport quality by various researchers (Redman et al., 2013). Some of the important dimensions of service quality that have been studied by different researchers under the SERVQUAL, SERPERF, or original measurement models are tangibles, reliability, responsiveness, assurance, 
empathy, safety, accessibility, service planning and reliability, comfort and ancillary factors, network design, flexibility, service provisions etc.(Morton et.al., ibid).

Fick \& Ritchie (1991) provided an initial application of SERVQUAL in the airline industry wherein they illustrated how the SERVQUAL measurement made an important and valuable contribution to the area of perceived service quality measurement. Pakdil and Aydin (2007) developed a modified version of SERVQUAL that extended the original service quality dimensions to include issues of image, flight experience and availability of interchange. Their result demonstrated that "responsiveness" is the most important dimension while "availability" is the least important element of quality. The application of SERVPERF approach, by Abdullah et al. (2012), found tangibility, reliability and assurance to be the strong service quality factors determining the performance of the airline providers. Pérez et al. (2007) used SERVPERF approach to study the service quality in bus services to examine the relationship between the service quality and the purchase intention. The findings of their study confirm a positive relationship between the five dimensions of service quality and purchase intention. Additionally, their study suggested the existence of "saturation point", beyond which further increase in service quality did not lead to increased patronage. Findings of Susnienè (2012) seconded Pérez et al. (2007); wherein it illustrated that each dimension was identifiable and that bus commuters express relatively large levels of dissatisfaction with the empathy of bus employees. The SERVPERF scale has also seen modification in the transport sector, with de Oña et al. (2014) providing a longitudinal analysis of changes in perceived quality of bus transit systems in Spain. Their analysis indicates that, in general, passengers are more dissatisfied with fare, frequency and timetable, and most satisfied with courtesy and safety.

Apart from SERVQUAL and SERVPERF approaches, a number of research studies investigating perception of transport service quality utilized original measurement methods to evaluate the service quality concept. Prioni and Hensher (2000) developed a stated preference model of service quality choice, known as service quality index (SQI), that provided the set of indicators required to represent a commuter-based measure of service quality. SQI provided an operationally appealing measure of service effectiveness to assist regulators in administering and monitoring a performance assessment regime and operators in improving customer service. Eboli and Mazulla (2007) developed a service quality measurement scale for bus transit that identified three quality dimensions namely; planning and reliability, network design and comfort and ancillary factors. Their analysis indicated that only the comfort and ancillary factors affected the perceived satisfaction of the passengers. Results of Chou et al. (2014) indicated that the five service quality attributes in high speed rail services with which passengers most agreed were cleanliness, followed by neat appearance of employee, employee service attitude, comfort of air conditioning, and on-time performance. Findings of the study also revealed that service quality had a positive effect on customer satisfaction and customer loyalty, while customer satisfaction had a positive effect on customer loyalty. Stradling et al. (2007) utilized a 68 item measurement scale to evaluate the service aspects which current bus users dislike about the service in Edinburgh. Eight underlying factors were reported: feeling unsafe, preference for walking or cycling, problem with service provision, unwanted arousal, preference for car use, cost, disability and discomfort, and self image.

Lai and Chen (2011) deployed an original measurement scale of perceived service quality which identifies two dimensions associated with core transit services and physical environment. These two dimensions significantly affected perceived satisfaction. Further, 
Şimşekoğlu et al. (2015) developed an original measurement scale of perceived service quality which identified three dimensions namely; safety, convenience and flexibility. The study found that priority of convenience, priority of safety and security, and favorable attitudes towards public transport use were positive predictors of intentions to use public transportation, while car use habit was a negative predictor of both intentions to use public transportation and reported public transportation use.

Yaya et al. (2014) adopted a mixed method approach combining management interviews, existing literature and commuters' survey to assess bus public transport service. The results of the study indicated that Functional (items related to aesthetic, assurance, empathy and responsiveness), Physical Environment (items related to atmosphere, comfort, ease of access, safety and security) and Convenience (items related to reliability, efficiency and suitability) represent the underlying dimensions of the customer perceived service quality in public transport setting. An in-depth assessment of customer opinion to understand perceived service quality in bus transit was also carried out by Carreira et al. (2014) and Mohamed and Hine (2016).

Hence, it can be concluded that while there are number of dimensions for service quality assessment in the transport sector using any of the above three approaches SERVQUAL, SERVPERF and original measurement instrucment, one aspect is very apparent and that is the overlap of the dimensions of the service quality. In this research study, the author has adopted SERVPERF approach. There were as many as twenty two constructs taken into consideration to capture the perception of commuters' towards the service quality of BRTS in the three cities of Ahmedabad, Rajkot and Surat.

\section{Study Area Profile}

The cities that have been taken for the study are Ahmedabad, Rajkot and Surat in the state of Gujarat, located in western India. As per the Census 2011 report, the population of Ahmedabad, Rajkot and Surat are 6.3 million, 1.4 million and 4.6 million respectively. In terms of the area too, Ahmedabad is the largest city spread over 464 sq.km followed by Surat with 326.5 sq.km and Rajkot with 170 sq.km. The literacy rate of Ahmedabad is marginally above Rajkot and Surat; while in terms of the sex ratio Rajkot fairs better compared to Ahmedabad and Surat with 906 females for every 1000 males (see Table 1 for details).

The city-wise modal split for all the three cities reveal that private transport share in the modal split is higher than the public transport share for all the three cities. Even the nonmotorized transport share is healthy, which indicates that a good share of the commuters either walk or use cycles to commute. Coming down to the BRTS system related information, one should not that all the three urban local bodies have floated special purpose vehicles (SPVs) to run the BRTS services in the concerned three cities. They operate under the names Janmarg, Rajpath, SitiLink in the cities of Ahmedabad, Rajkot and Surat respectively. Additionally, all the three cities run their bus operations on the gross-cost contract basis where the fare-box revenue risk is on the shoulders of the SPVs and not on the private bus operator. Janmarg, Rajpath and SitiLink commenced their operations in the year 2009, 2012 and 2014 respectively. This makes the Janmarg of Ahmedabad the oldest system among the three. Station spacing for the three cities range from 526.3 metres to 645.7 metres. All the three cities enjoy median position of withflow lanes. I.e. all the three BRT systems are close ended system, with BRTS lanes running at the centre and mixed lanes for other vehicels running parallely side by side. Janmarg is the largest system with $82 \mathrm{~km}$ system length and daily demand being 
approximated 0.13 million passengers per day. Vehicle fare collection in all the three systems is off-board fare collection (see Table 1 for details).

\section{Research Methodology:}

\subsection{Questionnaire and measures}

In order to capture the commuters' perception toward service quality of BRTS, the researcher prepared a questionnaire that comprised of two parts. The first part captured various demographic details of the respondents such as age, gender, educational qualification, employment status, frequency of BRTS usage, time of travel and so on. The second part of the questionnaire dealt with twenty two constructs. The selection of constructs, pertaining to tangibles, reliability and empathy, is largely inspired from the work of Parasuraman et al. (1988), Cronin and Taylor (1992), Kokku et al. (2011). While the constructs related to safety and accessibility are largely inspired from the works of de Oña et al. (2014). The constructs were measured on a 4 point Likert's scale with $1=$ Strongly Disagree, 2 = Disagree, $3=$ Agree and $4=$ Strongly Agree.

\subsection{Sampling, data collection and the statistical tests used}

The target group for the survey was the BRTS commuters, above the age thirteen, in the cities of Ahmedabad, Surat and Rajkot. The respondents of the survey were on-board passengers of the BRT systems of the three cities. In order to capture the wide variety of respondents, all the major routes of BRT systems of the concerned cities were taken into account. Data collection took around three weeks. Data collection was done both during the week days and weekends. Data was also collected both during the peak hours (08:00 hrs $-12: 00 \mathrm{hrs}$ and 16:00 hrs to 21:00 hrs) and non peak hours (hours other than peak hours) so that we get the near real representation of the BRTS users. After ommission of incomplete or invalid questionnaires, 386 valid samples were taken into further analysis.

Cronbach's alpha test was conducted to test the reliability of the constructs for factor analysis. Cronbach's alpha value ranges from 0 to 1 , with value closer to 1 indicating greater stability and consistency. The result of Cronbach's alpha are shown in Table 3, which shows value of 0.891 , indicating an acceptable consistency and stability of the instrument. Subsequent to the reliability test, all the constructs were found to be reliable as the alpha coefficients for all the constructs were above 0.7 (see Table 3). Principal Component Analysis is the extraction method used to extract factors under the factor analysis method. The number of factors have been decided on the percent variation basis $(>60 \%)$. In doing so the eigen value of fifth and sixth factor has come down to 0.990 and 0.967 respectively. Subsequently Independent samples Kruskal-Wallis Test and Independent samples Mann-Wittney U Test are used to test the hypotheses to identify the differences in perception towards quality of service attitudes across demographic cohorts.

\section{Data Analysis:}

\subsection{Respondents' demographic profile}

The respondents' demographic profile is summarized in the Table 2. It could be observed that out of the total 386 respondent, 83.7 percent of the respondents are below or up to the age of 40 years. When it comes to the gender of the respondents, it could be 
observed that majority of them are male commuters (68 percent). A good chunk of the respondents possess higher secondary education (32.6 percent) and graduation (38.3 percent) as their education qualification. Among the respondents, majority of them are students (44 percent), salaried (27.5 percent) and self employed/ daily wagers (16.6 percent). The fact that around 51 percent of the respondents have been using BRTS from last 1 to 3 years is a welcome trend. However, the lower percentage share of the respondents who are using BRTS for more than 3 years should be treated with care and concern. The daily commuters among the respondent are 46.6 percent and those who travel weekly are 21.2 percent. Although numbers are decent, efforts should be put to increase the share of daily and weekly commuters. The purposes of respondents' travel are education, work and recreation with 42.2 percent, 33.2 percent and 24.6 percent share respectively. The length of the one-way passenger trip of the respondents ranges from 6 $\mathrm{km}$ to $15 \mathrm{~km}$ for 70.7 percent of the respondents.

\subsection{Factor analysis}

In order to identify suitable factors and related constructs, factor analysis is performed. But prior to factor analysis, as described in section 4.2 above, reliability test is conducted and all the constructs are taken into consideration for further factor analysis. Subsequently, factor analysis using Principal Component Analysis approach with varimax rotation is conducted. Kaiser-Meyer-Olkin (KMO) measure of sampling adequacy with value 0.867 indicates that the sample size is adequate for factor analysis. Barlett's test of sphericity also has significant value, which indicates that the constructs are related and therefore suitable for structure detection. The results of KMO measure of sampling adequacy and Barlett's test of sphericity are shown in Table 3.

The factor analysis results using Principal Component Analysis extraction method resulted in extraction of six factors and the factor loading of different constructs is shown in Errore. L'origine riferimento non è stata trovata.. Looking into the nature of the constructs in each factors, it is observed that the six factors could be named as empathy, safety, tangibles, cleanliness, reliability and affordability. These factors are derived using "\% variation" as the criteria wherein percentage variation is greater than 60 percent. I.e. more than 60 percent of the variations in constructs are explained by the above derived six factors.

\subsection{Hypothesis testing to identify differences in perception towards quality of service attitudes across demographic cohorts}

Independent samples Kruskal-Wallis Test and Independent samples Mann-Wittney U Test are used to test whether the service quality perceptions, which cover the identified six dimensions found using factor analysis, vary across independent demographic variables such as the city the commuter belongs to, gender, age, education, employment status, travel-time, and so on. The tests are conducted at the significance level $(\alpha)$ of 0.05 . The hypotheses and the associated statistical techniques, and the results of the hypothesis testing are presented in

Table 4. The null hypothesis is rejected whenever " $\mathrm{P}<.05$ ". Examining the results of the hypothesis testing, a number of statistically significant differences have been observed with respondent demographic variables displaying distinct perceptions towards perceived quality of service. 
In terms of the city the respondent belongs to, attitude towards all the six dimensions vary, with respondents from Surat city showing a tendency to state higher levels of perceived quality followed by the respondents from Rajkot and Ahmedabad. Surat city tops in four out of six dimensions namely; safety, cleanliness, reliability and affordability. Rajkot city shows a tendency to state higher levels of perceived quality for the dimension tangibles and the Ahmedabad city shows a tendency to state higher levels of perceived quality for the dimension empathy. Significant difference is observed across only one dimension safety in terms of the gender of the respondent, with female respondents showing a tendency to state higher levels of perception towards safety dimension. Attitude towards various dimensions of perceived service quality of BRTS does not vary significantly across respondents of different age categories. Similar is the case of attitude towards various dimensions of perceived service quality across the frequency of BRTS usage.

In terms of education qualification of the respondents, significant differences are observed for tangibles, reliability and affordability. It is observed that respondents with increasing education qualification tend to display relatively lower levels of perception towards tangibles. While coming down to perception towards reliability and affordability it is observed that the respondents with education qualification less than post graduation tend to display unfavourable perception towards the said service quality. Focusing on the employment status of the respondents, significant variation in attitude towards safety and cleanliness are observed across the employment status of the respondents. Here, respondents from students category tend to display relatively unfavourable levels of perception towards safety, and respondents from professionals and students categories tend to display relatively unfavourable levels of perception towards cleanliness.

Significant differences are observed across perceptions towards empathy and tangibles in terms of the time of the travel made. It is observed that respondents traveling during non-peak hour tend to display relatively higher perception towards service quality dimensions pertaining to empathy and tangibles viz-a-viz respondents traveling during peak hour. In terms of the purpose of BRTS trip made by the respondents, significant difference is observed only for the attitude towards cleanliness. Respondents with trip purpose being work, and recreation and other tend to hold relatively positive attitude toward cleanliness; whereas respondents who make trip with education purpose have a propensity to display negative loading on the cleanliness. Lastly, focusing on the length of patronization of BRTS services (i.e. for how long the respondents have been using BRTS), it is observed that perceptions towards empathy, cleanliness, reliability and affordability vary across the length of patronization. With longer association with BRTS, respondents tend to display relatively higher perception towards empathy. Whereas, the same pattern is not observed when we dig into statistics pertaining to perception towards cleanliness, reliability and affordability. With longer association with the BRTS, the respondents tend to state lower levels of perceived quality of cleanliness, reliability and affordability.

\section{Conclusion}

The primary objective of the study is to inquire into the BRTS commuters' perception towards different service quality dimensions through a detailed evaluation of the quality of service indicators for BRTS in the cities of Ahmedabad, Rajkot and Surat. Factor analysis performed on twenty two constructs identified six quality of BRTS services 
indicators covering issues related to perceived empathy, safety, tangibles, cleanliness, reliability and affordability. The dimensions of the perceived service quality identified in the factor analysis appear to vary significantly across all demographic cohorts but age of the respondents and the frequency of usage.

The results of the analysis described in the above section indicate that Surat tends to state higher levels of perceived quality for the dimensions related to safety, cleanliness, reliability and affordability compared to the counterparts from Rajkot and Ahmedabad. In terms of the perception towards the tangibles and empathy Rajkot and Ahmedabad respectively tops the list. Among all the three cities, Ahmedabad has higher tendency to state lower levels of perceived quality for majority of the dimensions. These observations when read with the fact that Ahmedabad has the oldest BRT system followed by Rajkot and Surat chronologically, reveals that the perception of quality of the service drops with aging system.

The study reveals that female tends to state higher level of perception towards safety compared to that of male respondents. While on one hand the respondents with higher education qualification tends to hold more negative attitude towards tangibles; on the other hand the respondents with post graduation qualification tends to state higher levels of perceived quality for the dimensions reliability and affordability. While students have propensity to hold more negative attitude towards safety and cleanliness, the professionals have tendency to hold negative attitude towards cleanliness and positive attitude towards safety. Retirees, housewives and unemployed (all falling in the category 'others'), shows propensity to hold more positive attitude towards cleanliness and safety. Similarl, is the attitude of self employed/ daily wager and salaried respondent towards safety and cleanliness dimensions. Non-peak hour commuters tend to state higher levels of perceived quality for empathy and tangibles compared to their counterparts traveling during peak hours. Work and recreation and other purpose related trips have tendency to state higher levels of perceived quality for cleanliness whereas education related trips have tendency to state lower levels of perceived quality for cleanliness. Commuters who have been associated/ using BRTS for more than 3 years, i.e. respondents with longer patronization, have propensity to hold more negative attitude towards cleanliness, reliability and affordability. However, for the attitude towards empathy, the respondents who have been using BRTS for less than a year have propensity to hold more negative attitude.

The above findings mean that commuters from different life-stages and circumstances hold distinctive attitudes regarding the perceived quality of service. Understanding the differences in attitudes across different demographic cohorts can be useful in targeting service improvements. SPVs of the concerned three cities can make required improvements in different areas of quality of service to take the overall perception towards BRTS service quality northward. It can help SPVs managing public transport services to identify which service quality factors are considered most important by their customers. Also, they need to understand that such kind of studies are important not only to retain the existing customers but also to add the new ones to their systems. Demand side service quality measurements, like the one performed here, are done relatively on a regular interval of times in developed world countries. However, urban local bodies in India and other developing and under developed countries don't perform such exercises at regular intervals. However, it needs to be understood that perception towards quality of service keeps changing with experience(s) gained over a period of time, and therefore tracking them proactively will ensure that the overall satisfaction of the customers is taken care of so that the delighted customer will not only get retained but also spread positive 
word of mouth for the services. Such studies can give opportunites to carve out tailormade services for different target customer-groups and also utilize the subsidies appropriately.

\section{Table 1: Study area information}

\begin{tabular}{|c|c|c|c|}
\hline Particulars & Ahmedabad & Rajkot & Surat \\
\hline \multicolumn{4}{|l|}{ General Information on Cities (Census 2011) } \\
\hline Population of the Urban Agglomeration & 6361084 & 1390640 & $4,591,246$ \\
\hline Area $(\mathrm{sq} \mathrm{km})$ & 464 & 170 & 326.5 \\
\hline Average Literacy (\%) & 88.16 & 87.3 & 87.83 \\
\hline Sex ratio & 899 & 906 & 753 \\
\hline \multicolumn{4}{|c|}{ City-wise Modal Split (source: http://brtdata.org) } \\
\hline Modal split \% public transport & 22 & 13 & 13 \\
\hline Modal split \% private transport & 42 & 38 & 31 \\
\hline Modal split \% non motorized transport & 36 & 49 & 56 \\
\hline \multicolumn{4}{|c|}{ BRT system related information (source: http://brtdata.org) } \\
\hline BRT system name & Janmarg & Rajpath & SitiLink \\
\hline City Bus Operation Contractual Arrangement & \multicolumn{3}{|c|}{ Gross Cost Contract } \\
\hline Position of with-flow lanes & \multicolumn{3}{|c|}{ Median } \\
\hline Vehicle fare collection & \multicolumn{3}{|c|}{ Off-board } \\
\hline Commencement of Operation (Year) & 2009 & 2012 & 2014 \\
\hline Daily demand (passenger per day) & 130000 & 7500 & 13500 \\
\hline Annual demand (passenger per year) & 39000000 & 2250000 & 4050000 \\
\hline System length $(\mathrm{km})$ & 82 & 10.7 & 10 \\
\hline Station spacing (in metres) & 645.7 & 600 & 526.3 \\
\hline
\end{tabular}

Table 2: Descriptive statistics of the respondents

\begin{tabular}{|c|c|c|}
\hline \multicolumn{3}{|c|}{ Name of the City } \\
\hline & Percent & Cumulative Percent \\
\hline Ahmedabad & 24.6 & 24.6 \\
\hline Surat & 36.8 & 61.4 \\
\hline Rajkot & 38.6 & 100.0 \\
\hline \multicolumn{3}{|c|}{ Time of Travel } \\
\hline & Percent & Cumulative Percent \\
\hline Non Peak Hour & 43.3 & 43.3 \\
\hline Peak Hour & 56.7 & 100.0 \\
\hline \multicolumn{3}{|c|}{$\begin{array}{l}\text { Age of the Commuter } \\
\end{array}$} \\
\hline & Percent & Cumulative Percent \\
\hline$<20$ years & 22.8 & 22.8 \\
\hline 21-30 years & 42.0 & 64.8 \\
\hline $31-40$ years & 18.9 & 83.7 \\
\hline $41-50$ years & 10.9 & 94.6 \\
\hline $51-60$ years & 3.9 & 98.4 \\
\hline$>60$ years & 1.6 & 100.0 \\
\hline \multicolumn{3}{|c|}{ Gender of the Commuter } \\
\hline & Percent & Cumulative Percent \\
\hline
\end{tabular}

\begin{tabular}{|c|c|c|}
\hline \multicolumn{3}{|c|}{ Employment Status } \\
\hline & Percent & Cumulative Percent \\
\hline $\begin{array}{c}\text { Self-Employed/ } \\
\text { DailyWagers }\end{array}$ & 16.6 & 16.6 \\
\hline Salaried & 27.5 & 44.0 \\
\hline Professionals & 6.7 & 50.8 \\
\hline Students & 44.0 & 94.8 \\
\hline Others & 5.2 & 100 \\
\hline \multicolumn{3}{|c|}{ Using BRTS since } \\
\hline \multicolumn{3}{|c|}{ Percent } \\
\hline < 1year & 39.9 & 39.9 \\
\hline 1 to 3 years & 50.8 & 90.7 \\
\hline 3 to 5 years & 8.8 & 99.5 \\
\hline > 5 years & .5 & 100.0 \\
\hline \multicolumn{3}{|c|}{ How Often is the BRTS Usage } \\
\hline Daily & Percent & Cumulative Percent \\
\hline Weekly & 46.6 & 46.6 \\
\hline Monthly & 21.2 & 67.9 \\
\hline Rarely & 17.4 & 85.2 \\
\hline \multicolumn{2}{|c|}{} \\
\hline
\end{tabular}




\begin{tabular}{|c|c|c|} 
Male & 68.1 & 68.1 \\
\hline Female & 31.9 & 100 \\
\hline \multicolumn{2}{|c|}{ Education Qualification of the Commuter } \\
\hline & Percent & Cumulative Percent \\
\hline $\begin{array}{c}\text { Secondary } \\
\text { Education }\end{array}$ & 14 & 14 \\
\hline $\begin{array}{c}\text { Higher Secondary } \\
\text { Education }\end{array}$ & 32.6 & 46.6 \\
\hline Graduation & 38.3 & 85 \\
\hline $\begin{array}{c}\text { Post Graduation } \\
\text { Sost }\end{array}$ & 15.0 & 100.0 \\
\hline
\end{tabular}

\begin{tabular}{|c|c|c|}
\hline \multicolumn{3}{|c|}{ Purpose of Usage of BRTS } \\
\hline & Percent & Cumulative Percent \\
\hline Work & 33.2 & 33.2 \\
\hline Education & 42.2 & 75.4 \\
\hline Recreation and other & 24.6 & 100.0 \\
\hline \multicolumn{3}{|c|}{ One-way Distance Travelled in BRTS } \\
\hline & Percent & Cumulative Percent \\
\hline $1-5 \mathrm{~km}$ & 26.4 & 26.4 \\
\hline $6-10 \mathrm{~km}$ & 50.0 & 76.4 \\
\hline $11-15 \mathrm{~km}$ & 20.7 & 97.2 \\
\hline$>15 \mathrm{~km}$ & 2.8 & 100.0 \\
\hline
\end{tabular}

Source: Author's analysis of the primary data collected through survey.

Table 3: Reliability Statistics, Related Item Statistics and Factor Loading

\begin{tabular}{|c|c|c|c|c|c|c|}
\hline \multicolumn{7}{|c|}{ Reliability Statistics } \\
\hline \multicolumn{2}{|c|}{ Cronbach's Alpha } & \multicolumn{5}{|c|}{0.891} \\
\hline & \multicolumn{5}{|c|}{0.892} \\
\hline \multicolumn{2}{|c|}{$\begin{array}{l}\text { Cronbach's Alpha Based on Standardized Items } \\
\text { Number of Items (I.e. Number of constructs) }\end{array}$} & \multicolumn{5}{|c|}{22} \\
\hline \multicolumn{7}{|c|}{ KMO and Barlett's Test } \\
\hline \multicolumn{2}{|r|}{ Kaiser-Meyer-Olkin Measure of Sampling Adequacy. } & \multicolumn{5}{|c|}{.867} \\
\hline \multirow{3}{*}{\multicolumn{2}{|c|}{ Bartlett's Test of Sphericity }} & \multicolumn{5}{|c|}{ Approx. Chi-Square $=3055.634$} \\
\hline & & \multirow{2}{*}{\multicolumn{5}{|c|}{$\begin{array}{c}\text { Df }=231 \\
\text { Sig. }=0.000\end{array}$}} \\
\hline & & & & & & \\
\hline \multicolumn{5}{|c|}{ Item Statistics } & \multicolumn{2}{|c|}{ Factor Loading } \\
\hline \multicolumn{2}{|c|}{ Constructs } & Mean & $\begin{array}{l}\text { Std. } \\
\text { Dev }\end{array}$ & $\begin{array}{l}\text { Cronbach's } \\
\text { Alpha if } \\
\text { Item Deleted }\end{array}$ & $\begin{array}{l}\text { Factor } \\
\text { Loadingg }\end{array}$ & $\begin{array}{c}\text { Factor } \\
\text { associated } \\
\text { with }\end{array}$ \\
\hline V1 & BRTS is modern looking transport & 3.33 & .664 & .888 & .571 & Tangibles \\
\hline V2 & BRTS physical facilities are visually appealing & 3.31 & .707 & .886 & 640 & Tangibles \\
\hline V3 & BRTS facilities/ layouts are differently-able friendly & 3.09 & .804 & .887 & .567 & Tangibles \\
\hline V4 & Inside environment of BRTS Bus is clean and hygienic & 3.42 & .695 & .886 & .760 & Cleanliness \\
\hline V5 & $\begin{array}{l}\text { Inside environment of BRTS Bus shelter is clean and } \\
\text { hygienic }\end{array}$ & 3.35 & .694 & .887 & .778 & Cleanliness \\
\hline V6 & BRTS employees are neat appearing & 3.30 & .751 & .883 & .564 & Cleanliness \\
\hline V7 & You don't have to wait too long to board a BRTS bus & 3.18 & .694 & .885 & 624 & Reliability \\
\hline V8 & BRTS buses ply on the scheduled time & 3.28 & .715 & .884 & .626 & Reliability \\
\hline V9 & You reach the destination BRTS station on time & 3.30 & 669 & .885 & .768 & Reliability \\
\hline V10 & $\begin{array}{l}\text { When you have a problem, BRTS shows sincere efforts } \\
\text { in solving it }\end{array}$ & 3.08 & .839 & .886 & .647 & Empathy \\
\hline V11 & $\begin{array}{l}\text { BRTS gives attention to women, children and } \\
\text { differently able persons }\end{array}$ & 3.06 & .801 & .889 & .641 & Empathy \\
\hline V12 & $\begin{array}{l}\text { BRTS has operating hours convenient to all its } \\
\text { customers }\end{array}$ & 3.18 & .717 & .886 & .679 & Empathy \\
\hline V13 & BRTS employees give personal attention to passengers & 2.91 & .831 & .888 & .815 & Empathy \\
\hline V14 & BRTS employees understand your specific needs & 3.03 & .782 & .887 & .751 & Empathy \\
\hline V15 & BRTS buses are not over-crowded & 2.89 & .878 & .886 & .624 & Safety \\
\hline V16 & $\begin{array}{l}\text { In BRTS buses you don't come across cases of pick- } \\
\text { pocketing or theft of their belongings }\end{array}$ & 3.24 & .786 & .886 & .766 & Safety \\
\hline
\end{tabular}




\begin{tabular}{|l|l|c|c|c|c|c|} 
V17 & $\begin{array}{l}\text { In BRTS buses you don't come across cases of } \\
\text { physical or sexual abuse }\end{array}$ & 3.35 & .745 & .885 & .659 & Safety \\
\hline V18 & BRTS bus drivers drive buses carefully and safely. & 3.13 & .825 & .886 & .535 & Safety \\
\hline V19 & $\begin{array}{l}\text { You can reach the nearest BRTS station from your } \\
\text { place without much hassle }\end{array}$ & 3.24 & .689 & .884 & .484 & Safety \\
\hline V20 & $\begin{array}{l}\text { BRTS buses are easily available whenever you want } \\
\text { them during their (BRTS) working hours }\end{array}$ & 3.36 & .697 & .885 & .567 & Tangibles \\
\hline V21 & You can afford BRTS bus fares & 3.48 & .665 & .889 & .817 & Affordability \\
\hline V22 & $\begin{array}{l}\text { The fares charged by BRTS are worth the services they } \\
\text { provide }\end{array}$ & 3.50 & .625 & .884 & .682 & Affordability \\
\hline
\end{tabular}

Source: Author's analysis of the survey data using SPSS.

\section{Table 4: Hypothesis Testing to Identify Differences in Quality of Service Attitudes across Demographic Cohorts}

\begin{tabular}{|c|c|c|c|c|c|c|c|c|c|c|c|c|}
\hline \multirow{2}{*}{ Demographic Cohorts } & \multicolumn{2}{|c|}{ Empathy } & \multicolumn{2}{|c|}{ Safety } & \multicolumn{2}{|c|}{ Tangibles } & \multicolumn{2}{|c|}{ Cleanliness } & \multicolumn{2}{|c|}{ Reliability } & \multicolumn{2}{|c|}{ Affordability } \\
\hline & Mean & SD & Mean & SD & Mean & SD & Mean & SD & Mean & SD & Mean & SD \\
\hline Name of the City & \multicolumn{2}{|c|}{$\mathbf{P}=.000$} & \multicolumn{2}{|c|}{$\mathbf{P}=.007$} & \multicolumn{2}{|c|}{$P=.002$} & \multicolumn{2}{|c|}{$\mathbf{P}=.007$} & \multicolumn{2}{|c|}{$P=.013$} & \multicolumn{2}{|c|}{$P=.000$} \\
\hline Ahmedabad & .423 & .551 & .078 & .888 & -.262 & .833 & -.181 & .977 & -.141 & .792 & -.291 & 1.004 \\
\hline Surat & -.347 & 1.125 & .153 & .997 & .024 & 1.084 & .197 & .966 & .169 & 1.038 & .263 & .867 \\
\hline Rajkot & .060 & .984 & -.195 & 1.044 & .144 & .987 & -.072 & 1.021 & -.071 & 1.063 & -.065 & 1.058 \\
\hline $\begin{array}{l}\text { Gender of the } \\
\text { Respondent }^{\mathrm{B}}\end{array}$ & \multicolumn{2}{|c|}{$\mathrm{P}=.318$} & \multicolumn{2}{|c|}{$P=.016$} & \multicolumn{2}{|c|}{$\mathrm{P}=.310$} & \multicolumn{2}{|c|}{$\mathrm{P}=.130$} & \multicolumn{2}{|c|}{$\mathrm{P}=.679$} & \multicolumn{2}{|c|}{$\mathrm{P}=.807$} \\
\hline Male & .029 & 1.001 & -.082 & 1.044 & .034 & 1.029 & $\begin{array}{ll}-.052 \\
\end{array}$ & 1.014 & .015 & 1.027 & -.015 & 1.033 \\
\hline Female & -.061 & 1.000 & .174 & .877 & -.073 & .935 & .111 & .963 & -.031 & .943 & .032 & .929 \\
\hline Age of the Respondent ${ }^{\mathrm{A}}$ & \multicolumn{2}{|c|}{$\mathrm{P}=.516$} & \multicolumn{2}{|c|}{$\mathrm{P}=.145$} & \multicolumn{2}{|c|}{$\mathrm{P}=.288$} & \multicolumn{2}{|c|}{$\mathrm{P}=.051$} & \multicolumn{2}{|c|}{$\mathrm{P}=.576$} & \multicolumn{2}{|c|}{$\mathrm{P}=.530$} \\
\hline$<20$ years & -.147 & 1.107 & -.046 & 1.099 & .134 & 1.085 & -.001 & .992 & -.019 & 1.023 & -.131 & .956 \\
\hline $21-30$ years & .057 & .980 & -.118 & 1.086 & -.040 & .968 & -.112 & 1.007 & -.045 & 1.020 & .042 & 1.009 \\
\hline $31-40$ years & .106 & .972 & .026 & .799 & -.118 & 1.108 & .147 & .914 & .092 & .974 & .030 & 1.114 \\
\hline $41-50$ years & -.020 & .813 & .315 & .849 & .072 & .901 & -.085 & 1.128 & -.096 & 1.026 & .075 & 1.016 \\
\hline $51-60$ years & -.295 & 1.213 & .302 & .565 & .198 & .585 & .519 & .957 & .214 & .840 & .122 & .515 \\
\hline$>60$ years & .198 & .814 & .580 & .099 & -.445 & .274 & .553 & .485 & .509 & .571 & -.407 & .757 \\
\hline Education $^{\mathrm{A}}$ & \multicolumn{2}{|c|}{$\mathrm{P}=.111$} & \multicolumn{2}{|c|}{$\mathrm{P}=.054$} & $\mathbf{P}=$ & 001 & $\mathrm{P}=$ & 694 & $\mathbf{P}=$ & 023 & $\mathbf{P}=$ & 046 \\
\hline Seconday Education & -.122 & 1.083 & -.172 & 1.115 & .223 & 1.067 & -.190 & 1.189 & -.054 & 1.013 & -.031 & .971 \\
\hline $\begin{array}{l}\text { Higher Secondary } \\
\text { Education }\end{array}$ & .145 & 1.046 & .116 & .988 & .049 & 1.081 & .021 & .944 & -.076 & 1.041 & -.094 & .896 \\
\hline Graduation & -.061 & .948 & -.096 & .932 & .037 & .912 & .092 & .957 & -.046 & .982 & -.038 & 1.148 \\
\hline Post Graduation & -.046 & .936 & .153 & 1.054 & -.409 & .873 & -.103 & 1.027 & .334 & .897 & .330 & .765 \\
\hline Employment Status ${ }^{\mathbf{A}}$ & $\mathrm{P}=$ & 981 & $\mathbf{P}=$ & 021 & $\mathrm{P}=$ & 058 & $\mathbf{P}=$ & 008 & $\mathrm{P}=$ & 354 & $\mathrm{P}=$ & 975 \\
\hline $\begin{array}{l}\text { Self-Employed/ } \\
\text { DailyWagers }\end{array}$ & .060 & .894 & .064 & .791 & -.250 & 1.097 & .173 & 1.011 & -.019 & 1.034 & -.028 & 1.120 \\
\hline Salaried & -.027 & 1.100 & .029 & .992 & .082 & 1.018 & .046 & .906 & -.091 & .834 & .042 & .899 \\
\hline Professionals & .007 & .992 & .356 & .653 & -.106 & .863 & -.026 & 1.161 & .303 & .803 & -.036 & .965 \\
\hline Students & -.013 & .981 & -.158 & 1.122 & .004 & .978 & -.153 & 1.006 & .014 & 1.085 & -.002 & 1.056 \\
\hline Others & .057 & 1.026 & .524 & .533 & .465 & .758 & .539 & .961 & .033 & 1.169 & -.063 & .681 \\
\hline Time of Travel ${ }^{\mathrm{B}}$ & $\mathbf{P}=$ & 009 & $\mathrm{P}=$ & 824 & $\mathbf{P}=$ & 002 & $\mathrm{P}=$. & 348 & $\mathrm{P}=$ & 161 & $\mathrm{P}=$ & 297 \\
\hline Non Peak Hour Travel & .106 & 1.081 & -.019 & 1.041 & .144 & 1.027 & .037 & 1.042 & -.091 & 1.018 & -.074 & 1.005 \\
\hline Peak Hour Travel & -.081 & .928 & .014 & .970 & -.110 & .967 & -.028 & .968 & .070 & .983 & .056 & .995 \\
\hline $\begin{array}{l}\text { Frequency of the BRTS } \\
\text { travel }^{\mathrm{A}}\end{array}$ & $\mathrm{P}=$ & 429 & $\mathrm{P}=$ & 207 & $\mathrm{P}=$ & & $\mathrm{P}=$. & & $\mathrm{P}=$ & & $\mathrm{P}=$ & \\
\hline
\end{tabular}




\begin{tabular}{|c|c|c|c|c|c|c|c|c|c|c|c|c|}
\hline Daily & .040 & .978 & -.051 & .995 & .068 & 1.047 & -.063 & .976 & .017 & 1.012 & .010 & .991 \\
\hline Weekly & -.056 & .909 & .105 & .858 & -.093 & .903 & .108 & .999 & .078 & .997 & .088 & 1.017 \\
\hline Monthly & .084 & 1.033 & .227 & .804 & .076 & .856 & .110 & 1.020 & -.109 & .964 & .037 & .896 \\
\hline Rarely & -.145 & 1.152 & -.257 & 1.316 & -.169 & 1.125 & -.085 & 1.052 & -.037 & 1.022 & -.202 & 1.112 \\
\hline $\begin{array}{l}\text { Purpose of Usage of } \\
\text { BRTS }^{A}\end{array}$ & \multicolumn{2}{|c|}{$\mathrm{P}=.450$} & \multicolumn{2}{|c|}{$\mathrm{P}=.328$} & \multicolumn{2}{|c|}{$\mathrm{P}=.109$} & \multicolumn{2}{|c|}{$P=.032$} & \multicolumn{2}{|c|}{$\mathrm{P}=.301$} & \multicolumn{2}{|c|}{$\mathrm{P}=.343$} \\
\hline Work & -.111 & 1.049 & .067 & .921 & -.160 & 1.074 & .120 & .959 & .109 & 1.006 & .075 & 1.019 \\
\hline $\begin{array}{l}\text { Length of Patronization of } \\
\text { BRTS service }^{\mathrm{A}}\end{array}$ & \multicolumn{2}{|c|}{$\mathbf{P}=.002$} & \multicolumn{2}{|c|}{$\mathrm{P}=.826$} & \multicolumn{2}{|c|}{$\mathrm{P}=.089$} & \multicolumn{2}{|c|}{$P=.001$} & \multicolumn{2}{|c|}{$P=.015$} & \multicolumn{2}{|c|}{$P=.000$} \\
\hline$<1$ year & -.237 & 1.187 & .024 & .984 & .054 & 1.044 & .227 & .920 & .091 & 1.038 & .167 & .959 \\
\hline 1 to 3 years & .111 & .840 & -.033 & 1.060 & .011 & .989 & -.141 & 1.034 & .008 & .976 & -.020 & .990 \\
\hline
\end{tabular}

Source: Author's analysis of the survey data using SPSS.

\section{References}

Abdullah, K., Jan, M. T., \& Manaf, N. H. (2012) "A Structural Equation Modelling Approach to Validate the Dimensions of SERVPERF in Airline Industry of Malaysia", International Journal of Engineering and Managemet Sciences, 3 (2), 134-141.

Andreassen, T. W. (1994) "Satisfaction, Loyalty, Reputation as Indicators of Customer Orientation in the Public Sector", International Journal of Public Sector Management, 7 (2), 16-34.

Asubonteng, P., J., M. K., \& Swan, J. E. (1996) "SERVQUAL Revisited: A Critical Review of Service Quality", Journal of Service Marketing , 62-81.

Berry, L., Zeithaml, V., \& Parasuraman, A. (1985) "Quality Counts in Service Too", Business Horizons, 30-41.

Bolton, R.N. \& Drew, J.H. (1991a) "A Longitudinal Analysis of the Impact of Service Changes on Customer Attitudes", Journal of Marketing, 55, 1-9.

Boulding, W., Kalra, A., Staelin, R., \& Zeithaml, V. (1993) "A Dynamic Process Model of Service Quality: From Expectation to Behavioural Intentions", Journal of Marketing Research, 30, 7-27.

Brady, M., \& Cronin, J. (2001) "Some New Thoughts on Conceptualising Perceived Service Quality: A Hierarchical Approach", Journal of Marketing, 65 (3), 34-49.

Carreira, R., Patrício, L., Natal Jorge, R., \& Magee, C. (2014) "Understanding the Travel Experience and its Impact on Attitudes, Emotions and Loyalty towards the Transportation provider:A Quantitative Study with Mid-Distance Bus Trips", Transport Policy, 31, 35-46.

Chou, P., Lu, C., \& Chang, Y. (2014) "Effects of Service Quality and Customer Satisfaction on Customer Loyalty in High-speed Rail Services in Taiwan", Transportmetrica A: Transport Science, 10 (10), 917-945.

Cronin, J. J., \& Taylor, S. A. (1992) "Measuring Service Quality: A Reexamination and Extension", Journal of Marketing, 56 (3), 55-68.

Cronin, J. J., \& Taylor, S. A. (1994) "SERVPERF versus SERVQUAL: Reconciling Performance-Based and Perception-Minus-Expectations Measurement of service Quality", Journal of Marketing, 58 (1), 125-131.

Crosby, Philip B. (1979) "Quality is Free: The Art of Making Quality Certain", New York: New American Library

de Oña, R., Eboli, L., \& Mazzulla, G. (2014) "Monitoring Changes in Transit Service Quality over Time", Procedia - Social and Behavioral Sciences, 111, 974-983. 
Eboli, L., \& Mazzulla, G. (2007) "Service Quality Attributes Affecting Customer Satisfaction for Bus Transit", Journal of Public Transportation, 10 (3).

Fick, G., \& Ritchie, J. (1991)"Measuring Service Quality in the Travel and Tourism Industry", Journal of Travel Research, 30 (2), 2-9.

Garvin, David A. (1983), "Quality on the Line",Harvard Business Review, 61, 65-73.

Grönroos, C. (1984) "A Service Quality Model and its Marketing Implications",European Journal of Marketing, 18 (4), 36-44.

Grönroos, C. (1982) “An Applied Service Marketing Theory”,European Journal of Marketing, $16(7), 30-41$.

Kokku, R., AL-Motawa, A. A., \& Prince, V. J. (2011) "Measuring Commuters' Perception on Service Quality Using SERVQUAL in Public Transportation",International Journal of Marketing Strategies, 3 (1), 21-34.

Lai, W. T., \& Chen, C. F., (2011) "Behavioral Intentions of Public Transit Passengers - The Roles of Service Quality, Perceived Value, Satisfaction and Involvement", Transport Policy, 18(2), 318325.

Lewis, R. C. \& Booms, B.H. (1983)"The Marketing Aspects of Service Quality" in Emerging Perspectives on Services Marketing, L. Berry, G. Shostack, and G. Upah, eds., Chicago:American Marketing, 99-107.

Liu, B., Sudharshan, D., \& Hamer, L. (2000)“After-service Response in Service Quality Assessment : A Real-time Updating Model Approach”, Journal of Service Marketing, 14 (2), $160-177$.

Mohamed, M., \& Hine, J. (2016) "Measuring the Influence of Bus Service Quality on the Perception of Users", Transportation Planning and Technology, 39(3), 1-16.

Mazis, M.B., Ahtola, O.T., \& Klippel, R.E. (1975) "A Comparison of Four Multi-Attribute Models in the Prediction of Consumer Attitudes", Journal of Consumer Research, 2, 38-52.

Morton, C., Caulfield, B., \& Anable, J. (2016)“Customer Perceptions of Quality of Service in Public Transport: Evidence for Bus Transit in Scotland",Case Studies on Transport Policy, 4 (3), 199-207.

Oliver, Richard L. (1980) "A Cognitive Model of the Antecedents and Consequences of Satisfaction Decisions", Journal of Marketing Research, 17, 460-469.

Pakdil, F., \& Ãzlem, A. (2007)"Expectations and Perceptions in Airline Services: An Analysis Using Weighted SERVQUAL Scores",Journal of Air Transport Management, 13 (4), 229237.

Parasuraman, A., Berry, L., \& Zeithaml, V. (1991) "Refinement and Reassessment of the SERVQUAL Scale",Journal of Retailing, 67 (4), 420-450.

Parasuraman, A., Valarie, A., Zeithaml, V., \& Berry, L. (1988) "SERVQUAL: A Multiple-Item Scale for Measuring Consumer Perceptions of Service Quality",Journal of Retailing, 64 (1), $12-40$.

Parasuraman, A., Zeithaml, V., \& Berry, L. (1985) “A Conceptual Model of Service Quality and its Implications for Future Research",Journal of Marketing, 49, 41-50.

Parasuraman, A., Zeithaml, V., \& Berry, L. (1994) "Alternative Scales for Measuring Service Quality: A Comparative Assessment Based on Psychometric and Diagnostic Criteria",Journal of Retailing, 70 (3), 201-230.

Pérez, M. S., C., G. J., Carrillo, A. G., \& S., F. R. (2007) "Effects of Service Quality Dimensions on Behavioural Purchase Intentions: A Study in Public Sector Transport",Managing Service Quality: An International Journal, 17 (2), 134-151.

Prioni, P., \& Hensher. (2000) "Measuring Service Quality in Scheduled Bus Services", Journal of Public Transportation, 3 (2), 51-74.

Redman, L., Friman, M., Garling, T., \& Hartig, T. (2013) "Quality Attributes of Public Transport that Attract Car Users: A Research Review”, Transport Policy, 25, 119-127. 
Şimşekoğlu, Ö., Nordfjærn, T., \& Rundmo, T. (2015) “The Role of Attitudes, Transport Priorities, and Car Use Habit for Travel Mode Use and Intentions to Use Public Transportation in an Urban Norwegian Public", Transport Policy, 42, 113-120.

Singh, S. (2012), "Urban Transport in India: Issues, Challenges, and The Way Forward", European Transport $\backslash$ Trasporti Europei (An International Journal of Transport Economics, Engineering and Law, (52), 1-26.

Stradling, S., Carreno, M., Rye, T., \& Noble, A. (2007)"Passenger Perceptions and the Ideal Urban Bus Journey Experience",Transport Policy, 14 (4), 283-292.

Susnienè, D. (2012)“Quality Approach to the Sustainability of Public Transport",Transport, 27 (1), 102-110.

Terry, M., \& Julia, P. (2011) Understanding Urban Transportation Systems: An Action Guide for City Leaders, Centre for Research \& Innovation. Washington DC: National League of Cities.

Voss, B., Parasuraman, A., \& Grewal, D. (1998)"The Role of Price, Performance, and Expectations in Determining Satisfaction in Service Exchanges",Journal of Marketing, 62 (4), 46-61.

Yaya, L. H. P., Fortià, M. F., Canals, C. S., \& Marimon, F. (2014) "Service Quality Assessment of Public Transport and the Implication Role of Demographic Characteristics", Public Transport, 1-20.

Zahorik, A., \& Rust, R. (1992) "Modelling the Impact of Service Quality on Profitability: A Revie",. Advances in Services Marketing and Management, 1, 247-276.

Zeithaml, V., Berry, L., \& Parasuraman, A. (1996) "The Behavioural Consequences of Serivce Quality",Journal of Marketing, 60, 31-46.

Zeithaml, V., Parasuraman, A., \& Berry, L. (1985)"Problems and Strategies in Services Marketing", Journal of Marketing, 49, 33-46.

\section{Acknowledgements}

I would like to thank my students of MBA (Financial Management \& Business Laws) 2017-19 batch from Gujarat National Law University for their help in conducting the onboard bus surveys in the cities of Ahmedabad, Surat and Rajkot. 